\title{
ИННОВАЦИОННЫЕ НАПРАВЛЕНИЯ - ОСНОВА ПОВЫШЕНИЯ ЭФФЕКТИВНОСТИ ПРОИЗВОДСТВА ПРОДУКЦИИ РАСТЕНИЕВОДСТВА
}

\author{
Л.А. Хомутова (фото) \\ к.э.н., ведущий научный сотрудник отдела экономики \\ и бухгалтерского учёта \\ Л.М. Исаева \\ старший научный сотрудник отдела экономики \\ и бухгалтерского учёта \\ ФГБНУ «Костромской научно-исследовательский институт \\ сельского хозяйства», с. Минское
}

Сельское хозяйство Костромской области имеет животноводче-

\section{Растениеводство, производство, эффективность, инновации}

Crop production, production, efficiency, innovation ское направление. Интенсификация молочно-мясного скотоводства возможна при создании устойчивой собственной кормовой базы. Поэтому одной из главных задач отрасли растениеводства региона является обеспечение животноводства полноценными кормами. Производство картофеля, зерна и кормовых культур является составной частью агропромышленного комплекса Костромской области и предполагает тесную связь всех элементов производственно-технологического цикла: посевных площадей, валовых сборов сельскохозяйственных культур, закупочных цен, размещения и производственной инфраструктуры, рационального ведения и организации сельскохозяйственного производства на основе ресурсосбережения.

В 2017 г. в сельскохозяйственных организациях Костромской области общая земельная площадь составляла 226,2 тыс. га, что меньше на 90,8 тыс. га, или на 28,7\%, чем в 2013 г. Использовалось организациями $77 \%$, или 173,8 тыс. га земли. Площадь сельскохозяйственных угодий за анализируемый период сократилась на 24,7 тыс. га, или на 12,3\%, и составляла в 2017 г. 176,9 тыс. га, использовалось организациями 88,3\% угодий. В структуре сельскохозяйственных угодий на долю пашни приходилось $86 \%$ (152,1 тыс. га), использовалось организациями 138,9 тыс. га, или 91,3\%. На долю сенокосов приходилось 5,6\% (10,0 тыс. га) и пастбищ 8,1\% (14,3 тыс. га).

В 2017 г. вся посевная площадь составляла 144,5 тыс. га, сократилась на 13,5 тыс. га, или на 8,5\% по сравнению с 2013 г. В структуре посевных площадей многолетние травы занимали 67,3\%, зерновые культуры - 21,6, однолетние травы - 9,4, картофель - 0,7, овощи открытого грунта - 0,1\%.

Производственные показатели в растениеводстве в сельскохозяйственных организациях Костромской области в 2013-2017 гг. представлены в таблице 1. 
Таблица 1 - Показатели производства и реализации продукции растениеводства в сельскохозяйственных организациях Костромской области (2013-2017 гг.)

\begin{tabular}{|c|c|c|c|c|c|}
\hline \multirow{2}{*}{ Показатель } & \multicolumn{5}{|c|}{ Год } \\
\hline & 2013 & 2014 & 2015 & 2016 & 2017 \\
\hline \multicolumn{6}{|c|}{ Зерновые культуры } \\
\hline Площадь посева, тыс. га & 38,2 & 36,0 & 33,9 & 32,9 & 30,7 \\
\hline Урожайность (после доработки), ц/га & 11,2 & 16,2 & 15,7 & 14,0 & 14,0 \\
\hline Валовой сбор (после доработки), тыс. т & 40,6 & 58,9 & 52,7 & 45,9 & 34,8 \\
\hline Себестоимость производства, руб./ц & 832,5 & 692,5 & 772,6 & 868,3 & 961,6 \\
\hline Уровень товарности, \% & 23,8 & 17,0 & 24,6 & 22,0 & 18,9 \\
\hline Цена реализации, руб./ц & 771,0 & 776,5 & 840,1 & 862,4 & 912,2 \\
\hline Уровень рентабельности продаж, \% & 9,5 & 10,9 & 13,5 & $-1,0$ & 7,6 \\
\hline \multicolumn{6}{|c|}{ Картофель } \\
\hline Площадь посадки, га & 852,0 & 994,0 & 1088,0 & 1106,0 & 954,0 \\
\hline Урожайность, ц/га & 179,7 & 216,9 & 217,9 & 198,2 & 220,3 \\
\hline Валовой сбор, тыс. т & 15,1 & 21,6 & 23,7 & 21,9 & 21,0 \\
\hline Себестоимость производства, руб./ц & 718,1 & 846,8 & 985,6 & 1171,6 & 1357,3 \\
\hline Уровень товарности, \% & 77,5 & 50,0 & 66,2 & 73,4 & 55,0 \\
\hline Цена реализации, руб./ц & 1064,1 & 1700,3 & 1907,2 & 1401,0 & 1729,0 \\
\hline Уровень рентабельности продаж, \% & 43,1 & 85,9 & 112,3 & 20,5 & 16,3 \\
\hline \multicolumn{6}{|c|}{ Кормовые культуры } \\
\hline Площадь всего, тыс. га & 115,9 & 112,4 & 116,2 & 111,2 & 111,1 \\
\hline в том числе: - однолетние травы & 12,7 & 11,7 & 14,8 & 13,3 & 13,6 \\
\hline - многолетние травы & 102,5 & 99,5 & 100,0 & 97,0 & 97,2 \\
\hline Урожайность сена, ц/га & 18,9 & 16,5 & 19,1 & 15,9 & 19,2 \\
\hline Валовой сбор сена, тыс. т & 57,1 & 51,4 & 58,4 & 50,4 & 55,2 \\
\hline Себестоимость сена, руб./ц & 94,6 & 137,9 & 119,6 & 123,5 & 123,7 \\
\hline Производство силоса, тыс. т & 164,2 & 159,5 & 203,0 & 181,6 & 209,3 \\
\hline Себестоимость силоса, руб./ц & 68,3 & 75,6 & 89,5 & 84,3 & 100,0 \\
\hline Производство сенажа, тыс. т & 51,2 & 43,6 & 28,8 & 27,9 & 37,4 \\
\hline Себестоимость сенажа, руб./ц & 105,1 & 133,5 & 112,7 & 100,4 & 124,0 \\
\hline Валовой сбор зелёной массы, тыс. т & 385,4 & 357,8 & 392,8 & 391,7 & 428,9 \\
\hline Себестоимость зелёной массы, руб./ц & 32,5 & 40,0 & 41,1 & 40,9 & 53,7 \\
\hline
\end{tabular}

За анализируемый период площадь посева под зерновыми культурами сократилась на 7,5 тыс. га, или на 19,6\%. В структуре зернового клина озимые занимали $8,1 \%$, яровые - 91,9\%. Урожайность зерна увеличилась на 2,8 ц/га, или на $25 \%$, валовой сбор уменьшился на 5,8 тыс. т, или на 14,3\%. В 2017 г. наблюдалось снижение объёма реализации зерна на 3,3 тыс. т, или на $33,7 \%$, товарности - на 4,9 п.п., уровня рентабельности продаж - на 1,9 п.п. при одновременном росте себестоимости на 129,1 руб./ц, или на $15,5 \%$ по сравнению с 2013 г. В структуре реализации на- ибольший удельный вес занимали овёс $(47,4 \%)$, пшеница $(27,5 \%)$ и ячмень $(15,9 \%)$. По классному составу производимое зерно являлось фуражным [1].

В 2017 г. площади посадки картофеля увеличились на 102 га, или на 12\%, возросли урожайность (на 40,6 ц/га, или 22,6\%), валовой сбор продукции (на 5,9 тыс. т, или 39\%), себестоимость производства (на 639,2 руб./ц, или 89\%) и цена реализации (на 664,9 руб./ц, или 62,5\%). При этом снизились уровень товарности (на 22,5 п. п.) и уровень рентабельности продаж (на 26,8 п.п.). 
Производством картофеля в основном занимались сельскохозяйственные организации Костромского муниципального района (ООО «Вива», ЗАО «Заволжское», ООО «Сущево», ОАО «Минское», ООО «Мечта», ООО «Костромской Картофель»), в которых было сосредоточено 77\% площадей посадки картофеля региона. Семеноводческие посадки картофеля размещались на площади 335,5 га (35,2\% от общей площади посадки) [2].

В 2017 г. площади под кормовыми культурами сократились, по сравнению с 2013 г., на 4,8 тыс. га, или на 4,1\%. В структуре кормовых культур на долю многолетних трав приходилось 87,5\%, однолетних трав - 12,2\%. Урожайность сена увеличилась на 0,3 ц/га, или на 1,6\%, меньше заготовлено сена на 1,9 тыс. т, или на 3,3\%, сенажа - на 13,8 тыс. т, или на 27\%, производство силоса больше на 45,1 тыс. т, или на 27,5\%, по сравнению с 2013 г.

Таким образом, отрасль растениеводства Костромской области характеризуется низкими производственными показателями, товарности и нестабильным уровнем рентабельности. Одной из причин неэффективного развития отрасли растениеводства региона, на наш взгляд, является нерациональное использование сель- ских территорий, их природного, демографического, экономического потенциалов. Снижение использования сельскохозяйственных угодий в хозяйственном ведении привело к массовому зарастанию их древесно-кустарниковой растительностью, а возделывание сельскохозяйственных культур с нарушениями севооборотов и по упрощённым технологиям привело к увеличению засорённости полей. Вместе с тем, в регионе имеются внутренние резервы для повышения эффективности развития отрасли за счёт внедрения инновационных направлений: организации интенсивного производства и освоения новых и усовершенствованных индустриальных технологий, использования биоклиматического потенциала, научно обоснованного размещения производства отдельных сельскохозяйственных культур [3].

Показатели эффективности инновационных технологий в растениеводстве в сельскохозяйственных организациях Костромской области представлены в таблице 2 .

Расчёты показали, что при внедрении инновационных технологий урожайность картофеля может увеличиться на 59,7 ц/га, или на 27,1\%, а зерна - на 16 ц/га, или на 114,3\%, при снижении

Таблица 2 - Показатели эффективности инновационных технологий в растениеводстве в сельскохозяйственных организациях Костромской области

\begin{tabular}{|c|c|c|}
\hline Показатель & Факт, 2017 г. & После внедрения \\
\hline \multicolumn{3}{|c|}{ Картофель } \\
\hline Площадь посадки, тыс. га & 1,0 & 1,1 \\
\hline Урожайность, ц/га & 220,3 & 280,0 \\
\hline Себестоимость, руб./ц & 1357,3 & 970,0 \\
\hline Уровень товарности, \% & 55,0 & 77,5 \\
\hline Уровень рентабельности, \% & 16,3 & 54,5 \\
\hline \multicolumn{3}{|c|}{ Зерновые культуры } \\
\hline Площадь посева, тыс. га & 30,7 & 45,0 \\
\hline Урожайность, ц/га & 14,0 & 30,0 \\
\hline Себестоимость, руб./ц & 961,6 & 785,0 \\
\hline Уровень товарности, \% & 18,9 & 40,0 \\
\hline Уровень рентабельности, \% & 7,6 & 21,0 \\
\hline \multicolumn{3}{|c|}{ Кормовые культуры } \\
\hline Площадь однолетних и многолетних трав, тыс. га & 110,8 & 150,0 \\
\hline Урожайность зелёной массы, ц/га & 112,0 & 300,0 \\
\hline Себестоимость зелёной массы, руб./ц & 53,7 & 31,4 \\
\hline Урожайность сена, ц/га & 19,2 & 50,0 \\
\hline Себестоимость сена, руб./ц & 123,7 & 95,0 \\
\hline
\end{tabular}


себестоимости на $28,5 \%$ и $18,4 \%$ и увеличении рентабельности в 3,3 и 2,8 раза соответственно. Площадь посева однолетних и многолетних трав увеличится на 39,8 тыс. га, или на $35,4 \%$. Рост урожайности зелёной массы и сена однолетних и многолетних трав в 2,6 раза приведёт к снижению себестоимости их производства на 41,5 и 23,2\% соответственно. Это позволит удешевить рационы кормления сельскохозяйственных животных, сократить в структуре затрат на производство продукции животноводства долю затрат на корма, что в конечном итоге отразится на снижении её себестоимости.

Решение вопроса устойчивого развития сельскохозяйственного производства связано с активизацией инновационной деятельности организаций. Освоение, внедрение и коммерциализация инноваций становится сегодня ключевым фактором роста и повышения эффективности производства.

В качестве основных направлений инновационной деятельности в отрасли растениеводства следует выделить:

1. Систему семеноводства сельскохозяйственных культур. Здесь необходимо обратить особое внимание на широкомасштабное использование сортов отечественной селекции для решения проблемы импортозамещения. Особое внимание следует уделить восстановлению системы первичного и товарного семеноводства многолетних трав с целью обеспечения всех сельских товаропроизводителей высококачественными семенами.
2. Внедрение на производстве экологически безопасных электронно-ионных технологий обработки и хранения сельскохозяйственной продукции, а также применение органоминеральных удобрений, гумата. Ресурсосберегающие технологии при выращивании сельскохозяйственных культур с учётом природно-климатических, агрохимических и агрофизических свойств почвы позволяют повысить эффективность аграрного производства. Ресурсосберегающие технологии с использованием элементов биологизации систем земледелия предусматривают внедрение сидеральных севооборотов, переход от постоянной вспашки к дифференцированным системам с приёмами минимальной обработки почвы, более экономные и экологически безопасные методы применения удобрений, применение более долголетних видов многолетних трав [4].

3. Внедрение механизма разделения аграрного сектора региона по зонам с учётом узкоспециализированного принципа ведения сельского хозяйства для ориентации на монопроизводство как наиболее эффективного и рационального использования материальных, денежных и трудовых средств, что является лучшей возможностью использования современных достижений наукоёмких технологий [5].

Комплексное проведение организационных, технологических и экономических мероприятий сможет повысить эффективность отрасли аграрного производства в регионе.

\section{Лumepamypa}

1. Гвазава, Д.Г. Эффективность производства зерновых культур в сельскохозяйственных организациях Костромской области [Текст] / Д.Г. Гвазава, Л.А. Хомутова, Л.М. Исаева // Вестник АПК Верхневолжья. 2018. - № 3 (43). - С. 64-68.

2. Гвазава, Д.Г. Эффективность производства картофеля в с.-х. организациях Костромской области [Текст] / Д.Г. Гвазава, Л.А. Хомутова, Л.М. Исаева // Картофель и овощи. - 2018. - № 8. - С. 23-25.

3. Исаева, Л.М. Применение ресурсосберегающих технологий при уборке зерновых культур на кормовые цели [Текст] / Л.М. Исаева, 3.И. Клинова // Основные итоги научных исследований по сельскому хозяйству в Центральном районе Нечерноземной зоны России (70 лет НИИСХ ЦРН3). - М.: Немчиновка, 2001. - С. 507-509.

4. Хомутова, Л.А. Совершенствование организационно-экономического механизма для создания условий рентабельного и устойчивого производства зерна Костромской области [Текст] / Л.А. Хомутова, Л.М. Исаева, Е.В. Кузнецова // Актуальные проблемы науки в агропромышленном комплексе: материалы 57-й международ. науч.-практ. конф. - В 2-х т. Т.2. - Кострома: Изд-во КГСХА, 2006. - С. 98-100.

5. Гвазава, Д.Г. Эффективность наукоемких технологий в антикризисном управлении аграрным производством [Текст] / Д.Г. Гвазава, А.Н. Ильченко. - М.: ФГОУ ВПО РГАУ- МСХА им. К.А. Тимирязева, 2005. - 228 с.

\section{References}

1. Gvazava, D.G. Jeffektivnost' proizvodstva zernovyh kul'tur v sel'skohozjajstvennyh organizacijah Kostromskoj oblasti [Tekst] / D.G. Gvazava, L.A. Khomutova, L.M. Isaeva // Vestnik APK Verhnevolzh'ja. - 2018. № 3 (43). - S. 64-68. 
2. Gvazava, D.G. Jeffektivnost' proizvodstva kartofelja v s.-h. organizacijah Kostromskoj oblasti [Tekst] / D.G. Gvazava, L.A. Khomutova, L.M. Isaeva // Kartofel'i ovoshhi. - 2018. - № 8. - S. 23-25.

3. Isaeva, L.M. Primenenie resursosberegajushhih tehnologij pri uborke zernovyh kul'tur na kormovye celi [Tekst] / L.M. Isaeva, Z.I. Klinova // Osnovnye itogi nauchnyh issledovanij po sel'skomu hozjajstvu v Central'nom rajone Nechernozemnoj zony Rossii (70 let NIISH CRNZ). - M.: Nemchinovka, 2001. - S. 507-509.

4. Khomutova, L.A. Sovershenstvovanie organizacionno-jekonomicheskogo mehanizma dlja sozdanija uslovij rentabel'nogo i ustojchivogo proizvodstva zerna Kostromskoj oblasti [Tekst] / L.A. Khomutova, L.M. Isaeva, E.V. Kuznetsova // Aktual'nye problemy nauki v agropromyshlennom komplekse: materialy 57-j mezhdunarod. nauch.-prakt. konf. - V 2-h t. T.2. - Kostroma: Izd-vo KGSHA, 2006. - S. 98-100.

5. Gvazava, D.G. Jeffektivnost' naukoemkih tehnologij v antikrizisnom upravlenii agrarnym proizvodstvom [Tekst] / D.G. Gvazava, A.N. I'chenko. - M.: FGOU VPO RGAU - MSHA im. K.A. Timirjazeva, 2005. - 228 s.

\section{ОБЫЯВЛЕНIИЕ}

\section{В издательстве ФГБОУ ВО Ярославская ГСХА в 2018 году вышла монография А.И. Голубевой, А.С. Карамышева}

\section{«ОБЕСПЕЧЕНИЕ ПРОДОВОЛЬСТВЕННОЙ БЕЗОПАСНОСТИ РЕГИОНА ПО ПРОДУКЦИИ ЖИВОТНОВОДСТВА»}

В монографии содержатся теоретические положения о сущности продовольственной безопасности, анализируется состояние обеспеченности пищевыми продуктами населения региона, обосновываются предложения по совершенствованию организационно-экономического механизма обеспечения продовольствием и направлений увеличения объемов производства молочной и мясной продукции до рекомендуемых нормативов. Кроме того, в монографии разработаны и апробированы методические рекомендации по оценке уровня продовольственной безопасности региона с акцентом на вопросы качества потребляемого продовольствия.

Предназначена для научных работников, магистрантов, аспирантов, обучающихся в сельскохозяйственных учебных заведениях, руководителей и специалистов сельского хозяйства.

УДК 636:338.439.5(470.316); ББК 65.32; ISВN 978-5-98914-195-1; 254 стр.

ПО ВОПРОСАМ ПРИОБРЕТЕНИЯ ОБРАЩАТЬСЯ ПО АДРЕСУ:

150042, г. Ярославль, Тутаевское шоссе, 58, ФГБОУ ВО Ярославская ГСХА

e-mail: e.bogoslovskaya@yarcx.ru 